\title{
Szervkonzerválás gépi perfúzióval: új lehetőségek a hasi szervek transzplantációjában
}

\author{
Wettstein Dániel dr..$^{1^{*}}$ - Hamar Mátyás dr. ${ }^{1^{*}}$ \\ Cseprekál Orsolya dr. ${ }^{1}$ : Tóth Szabolcs József ${ }^{2}$ - Rózsa Balázs dr. ${ }^{1}$ \\ Remport Ádám dr. ${ }^{1}$ - Máthé Zoltán dr. ${ }^{1}$
}

'Semmelweis Egyetem, Általános Orvostudományi Kar, Transzplantációs és Sebészeti Klinika, Budapest

${ }^{2}$ Semmelweis Egyetem, Általános Orvostudományi Kar, Budapest

\begin{abstract}
A modern transzplantációban a marginális szervek gépi perfúziója jelenthet egy lehetséges választ a várólistán lévő betegek növekvő halálozása és morbiditása miatt világszerte fokozódó szervigényre. A szervek beültetését megelőző aktív szervkonzerválás, a tárolás körülményeinek optimalizálása az utóbbi évek transzplantációs kutatásainak középpontjába került. A gépi perfúzió lehetőséget teremthet a szervek prezervációs károsodásának csökkentésére, rekondicionálására, a funkcionális paraméterek és biomarkerek beültetést megelőző értékelésére, a konzerválás időtartamának növelésére, valamint további terápiás eljárások egyidejü alkalmazására. Az új technológiák célja a transzplantációt követő szervfunkció javítása és a biztonsággal beültethető donorszervek számának növelése. A gépi perfúzió rövid és hosszú távú eredményeit multicentrikus vizsgálatok kutatják, a különböző módszerek előnyeirôl számos kérdés maradt még megválaszolatlan. Közleményünkben összegezzük a gépi szervkonzerválás eddigi vívmányait, a közelmúlt legfontosabb preklinikai és klinikai kutatási eredményeit, melyek alapján a gépi perfúziót a transzplantáció újabb mérföldkövének tekinthetjük.
\end{abstract}

Orv Hetil. 2018; 159(46): 1882-1890.

Kulcsszavak: szervtartósítás, szervtranszplantáció, hidegischaemia, melegischaemia, perfúzió

\section{Machine perfusion: new opportunities in abdominal organ transplantation}

Machine perfusion of marginal grafts might be a possible solution to organ shortage and a promising tool for reducing waiting list morbidity and mortality. In recent years, optimizing the circumstances of organ preservation prior to implantation via machine perfusion has become a hot topic of research. Machine perfusion offers a platform for organ reconditioning, assessment of cell viability and function, pharmacological preconditioning, prolongation of preservation time (ischemia time) and finally reducing graft injury. The objective of the new technology is to increase the pool of transplantable organs safely. Multicentric prospective studies have been evaluating the short and long term outcomes of different methods, however, several questions still remain unanswered. This review summarizes the recent advances in the field of machine perfusion, focusing on preclinical and clinical results. Machine perfusion seems to be a new milestone in the modern era of solid organ transplantation.

Keywords: organ preservation, organ transplantation, cold ischemia, warm ischemia, perfusion

Wettstein D, Hamar M, Cseprekál O, Tóth SzJ, Rózsa B, Remport Á, Máthé Z. [Machine perfusion: new opportunities in abdominal organ transplantation]. Orv Hetil. 2018; 159(46): 1882-1890.

(Beérkezett: 2018. augusztus 23.; elfogadva: 2018. szeptember 15.)

*A szerzők azonos mértékben vettek részt a kézirat elkészítésében. 


\section{Rövidítések}

ATP $=$ adenozin-trifoszfát COPE $=($ Consortium for Organ Preservation in Europe) Konzorcium a Szervtartósításért Európában; $\mathrm{COR}=($ controlled oxygenated rewarming $)$ kontrollált oxigenizált felmelegítés; $\mathrm{DCD}=$ (donation after cardiac death) szívhalált követő donáció; DGF $=($ delayed graft function) késve meginduló graftmúködés; $\mathrm{ECD}=($ extended criteria donation) kiterjesztett kritériumú donáció; eGFR = (estimated glomerular filtration rate) becsült glomerulusfiltrációs ráta; $\mathrm{ETl}=$ endothelin- $1 ; \mathrm{EVNP}=($ ex vivo normothermic perfusion) ex vivo normotermiás perfúzió; GST = glutation-S transzferáz; HBD = (heart beating donor) dobogó szívú donor; $\mathrm{H}-\mathrm{FABP}=$ (heart-type fatty acid binding protein) szív típusú zsírsavkötő fehérje; HMP = (hypothermic machine perfusion $)$ hipotermiás gépi perfúzió; HOPE $=$ (hypothermic oxigenated machine perfusion) hipotermiás oxigenizált gépi perfúzió; IGLl = (Institut Georges Lopez-1) Georges Lopez Intézet perfúziós oldat; $\mathrm{IL}=$ interleukin; $\mathrm{KIMl}=($ kidney injury molecule-1) vesekárosodással összefüggő molekula; $\mathrm{LDH}=$ laktát-dehidrogenáz; L-FABP = (liver-type fatty acid binding protein) máj típusú zsírsavkötő fehérje; NGAL = (neutrophil gelatinase-associated lipocalin) neutrofil zselatinázhoz asszociált lipokalin; $\mathrm{NMP}=($ normothermic machine perfusion $)$ normotermiás gépi perfúzió; $\mathrm{PNF}=$ (primary non-function $)$ primer graftelégtelenség; POMP $=($ pre-implantation oxygenated hypothermic machine perfusion) beültetést megelőző oxigenizált hipotermiás gépi perfúzió; $\mathrm{SCD}=$ (standard criteria donor) standard kritériumú donor; UNOS = (United Network for Organ Sharing) az Amerikai Egyesült Államok donorszervallokációs hálózata; UW = University of Wisconsin

Világszerte, így Magyarországon is jellemző, hogy a szervtranszplantációra váró betegek száma jelentősen meghaladja a rendelkezésre álló, beültethető szervek mennyiségét. A transzplantációk száma növelhető a donorként elfogadható szervek funkcionális kritériumainak észszerú kiterjesztésével (extended criteria donation, ECD). A kiterjesztett kritériumú szervek azonban fokozottan érzékenyek a szervkonzerválásból fakadó károsodásra, ami kedvezőtlenül hathat a várható graftmúködésre és túlélésre. A gépi perfúzió egy lehetséges stratégia a prezervációs károsodás csökkentésére.

A statikus hidegtárolás az anyagcsere-folyamatokat kevesebb, mint 10\%-ra lassítja, azonban bizonyos mértékú anaerob metabolizmus még 4 Celsius-fokon is mérhető [1]. Az ischaemia ATP-deplécióhoz, anaerob metabolitok felszaporodásához, ez pedig reaktív oxigén gyökök képződéséhez vezet, ami a következményes ischaemiásreperfúziós károsodások kulcstényezője [2]. Ezzel szemben a dinamikus gépi perfúzió már a tárolás ideje alatt elsősorban az alkalmazott munkahőmérséklettől függően - támogatja az alapanyagcsere-folyamatok fenntartását. $\mathrm{Ez}$ utóbbi alapján megkülönböztetünk hipotermiás, szubnormotermiás és normotermiás eljárásokat. A gépi perfúzió során a szervek speciális, magas energiájú szubsztrátokat tartalmazó oldattal perfundálhatók, a perfúziós oldat oxigenizálásával pedig még „fiziológiásabb" körülmények biztosíthatók, ezáltal hosszabb és biztonságosabb konzerválás válik lehetővé.

\section{A gépi perfúzió rövid története - vissza a jövőbe?}

A transzplantációs immunológia és a sebészi technikák fejlődése mellett a szervtranszplantációk sikerének elengedhetetlen feltétele volt a szervek megfelelő konzerválása. Kezdetben a pulzatilis perfúziós tárolás jelentette a standard szervkonzerválási módszert, mivel a szervek eltávolítása a klinikai halál beállta után a keringés nélküli testből történt, és más módon nem volt lehetőség a szervek hatékony hütésére. Az első szívtranszplantáció elvégzéséhez (melyhez dobogó szívü agyhalott donorra volt szükség) elengedhetetlenné vált a hagyományos haláldefiníciók átértékelése [3]. Ekkor hosszas szakmai egyeztetés eredményeként, 1968-ban született meg a harvardi agyhalál-koncepció [4]. Ezzel a donorprofil és a szervkivételi eljárás gyakorlata is gyökeresen megváltozott. Lehetőség nyílt a dobogó szívű agyhalottból (HBD) történő donációra, így a hasi nagyerek kanülálása után a graftok in vivo azonnali hatékony lehútésére, valamint a lényegesen egyszerúbb statikus hidegtárolásra és a szervek biztonságos szállítására. Ehhez azonban a modern konzerválóoldatok kifejlesztésére volt szükség, hogy az addig egyeduralkodó pulzatilis perfúziós tárolás komplex és körülményes technikáját rutinszerüen felválthassa az egyszerü hidegtárolás. Geoffrey Collins angol sebész 200 kutyán végzett vesetranszplantációs kísérletei alapján egyértelmúek voltak az eredmények az eljárás alkalmazhatóságát illetően, de a módszer elfogadása hoszszabb időt vett igénybe. Collins technikája fokozatosan épült be a klinikai gyakorlatba: az 1980-as évek közepéig világszerte még gyakran pulzatilis perfúziós transzportot használtak, az új módszer alkalmazása csak az 1990-es években érte el a 90\%-os gyakoriságot. A statikus hidegtárolás elterjedésében jelentős szerepe volt az F. Belzer és J. Southard által az 1980-as években kifejlesztett Viaspan, más néven University of Wisconsin (UW) oldat elterjedésének, ami máig széleskörúen használt prezervációs oldat. A vese-, máj- és hasnyálmirigy-transzplantáció területén is jelentős technikai előrelépések történtek az elmúlt 30 évben, de a szervek konzerválásában évtizedekig a statikus hidegtárolás maradt az elfogadott és alkalmazott eljárás [5]. A technikai fejlődésnek köszönhetően a közelmúltban újra előtérbe került a szervek gépi perfúzióval történő konzerválása, biztató előzetes eredményekkel.

\section{Gépi perfúzió a vesetranszplantációban}

A vesetranszplantációs várólistára kerülő betegek száma minden évben meghaladja az elérhető donorszervek számát. A donorkritériumok észszerü kiterjesztésével (ECD) lehet ezen javítani, illetve egyes országokban a szívmegállást követően végzett donáció bevezetésével (DCD) is próbálják ezt a hiányt mérsékelni [6-9]. Az Amerikai Egyesült Államok (USA) donorszerv-allokációs hálózatának (UNOS) definíciója szerint kiterjesztett 
donorkritériumokról beszélhetünk a vese vonatkozásában, ha a donor életkora 60 év feletti, illetve ha az alábbiak közül legalább két rizikótényező együttesen fennáll: a donor 50 és 60 éves közötti, hypertoniás, cerebrovascularis okból állt be az agyhalál, vagy a szervkivétel előtti szérumkreatinin-szint 132,6 $\mathrm{mmol} / \mathrm{l}$-nél magasabb. Az átültetést követően késve meginduló graftmüködés (DGF) a donorszerv minőségétől függően különböző mértékben érintheti a vesetranszplantáción átesett betegeket, és összességében mintegy 30\%-ra tehető az előfordulása [10-12]. A DGF nem csupán a rövid távú kezelést (például dialízisszükséglet) befolyásolja, hanem az akut rejekció előfordulásának is kockázati tényezője, továbbá növeli a későbbi krónikus nephropathia és graftvesztés incidenciáját. A UNOS kiterjesztett ismérvei szerint történő vesetranszplantációk esetén a DGF és PNF (primer graftelégtelenség) előfordulása szignifikánsan gyakoribb, mint a standard kritériumú donorok (SCD) esetén. A DGF kialakulásának egyik legfontosabb rizikófaktora a tartós ischaemia okozta károsodás. A gépi perfúzió által a szervkonzerválás körülményei optimalizálhatók, ami kiterjesztett kritériumú szervek esetében kiemelkedő jelentőséggel bír.

\section{Hipotermiás gépi veseperfúzió}

A hipotermiás $\left(4^{\circ} \mathrm{C}\right.$ fokon végzett) gépi perfúzió rövid és hosszú távú előnye a standard hidegtárolással szemben a több évtizedes klinikai tapasztalat ellenére csak napjainkban kezd letisztulni [13]. Számos metaanalízis és randomizált klinikai vizsgálat szolgál meggyőző evidenciával, hogy a hipotermiás gépi perfúziós (HMP) konzerválás csökkenti a DGF-rátát agyhalott donorokból származó veséknél a statikus hidegtárolással összehasonlítva [14-17]. Hasonló eredményeket igazoltak a DCD-donoroknál is [18], bár a két legnagyobb európai, randomizált kontrollcsoportos klinikai vizsgálat eredménye egymásnak ellentmondó. Az Eurotransplant gépi perfúziós vizsgálatának eredményei a DGF előfordulásának szignifikáns csökkenését mutatták [19], míg az Egyesült Királyságban végzett multicentrikus vizsgálat ezt nem támasztotta alá [20]. A két klinikai vizsgálat közötti lényeges különbség az eltérő metodikából is adódhat. Az Eurotransplant által végzett vizsgálat során a donorból eltávolított szervet azonnal pumpára tették, míg az Egyesült Királyságban a HMP-t megelőzően a graftokat statikus hidegtárolással konzerválták a donor- és recipienscentrumok közötti szállítás során.

A HMP hosszú távú előnyéről még kevesebb meggyőző klinikai bizonyíték áll rendelkezésre: az 1, illetve 3 éves grafttúlélés tekintetében csak az ECD-transzplantációknál mutatkozott jelentős javulás, a DCD-transzplantációknál nem [21, 22]. A gépi perfúziós tárolás közben a vese viabilitásának megítélése a kutatások központi témaköre. A HMP során mért artériás áramlás és rezisztenciaindex összefügg a DGF és PNF előfordulási gyakoriságával $[23,24]$, de ezek prediktív értéke a klinikai

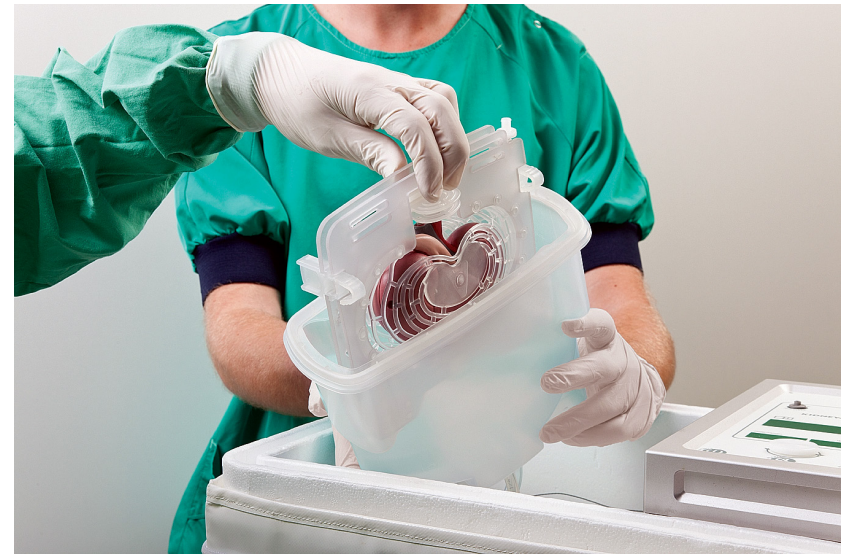

1. ábra

Hipotermiás gépi veseperfúzió, a vese kiemelése a gépből (Kidney Assist ${ }^{\circledR}$, Organ Assist, Groningen, Hollandia; a cég engedélyével)

gyakorlatban szerény. Hasonlóan, a perfuzátumból detektálható biomarkerek, mint az LDH, GST és a H-FABP szintje sem megfelelő előrejelzői a DGF-nek és a PNFnek. Az IL18 szintje bizonyítottan összefüggést mutat a korai és késői graftfuncióval, klinikai alkalmazhatósága azonban önmagában szintén megkérdőjelezhető [2527]. Egy napjainkban publikált, nagy esetszámú (n = 671), prospektív klinikai tanulmányban Parikh és mtsai számos biomarker (NGAL, L-FAPB, IL18 és a KIMl), valamint pumpaparaméter (áramlás, rezisztenciaindex) összefüggését vizsgálta a vesetranszplantáció kimenetelével. Eredményeik alapján a perfuzátum NGAL- és H-FABP-értéke, illetve a rezisztenciaindex mérsékelten korrelált a 6 hónapos eGFR-értékekkel [22, 28].

Preklinikai adatok alapján a perfúziós oldat aktív oxigenizálása a hidegperfúzió során helyreállítja a mitokondriális ATP-szintézist, amellyel az ischaemiás-reperfúziós károsodás mértéke jelentősen mérsékelhető [29]. A hipotermiás oxigenizált gépi perfúzió (HOPE) klinikai hatásosságáról jelenleg korlátozottan állnak rendelkezésre irodalmi adatok. Napjainkban két átfogó nemzetközi, multicentrikus, randomizált klinikai kutatás (COPEPOMP és COPE-COMPARE) folyik az Eurotransplantrégióban, többek mellett a Semmelweis Egyetem Transzplantációs és Sebészeti Klinikájának részvételével. Az első prospektív vizsgálat az oxigenizált HMP hatásosságát veti össze a kizárólag hidegtárolással tartósított ECD-vesék esetén. A második vizsgálatban az anoxiás és oxigenizált gépi perfúzió védőhatását hasonlítják össze. A vizsgálat beválogatási fázisa lezárult, jelenleg az egyéves betegkövetés zajlik.

Hipotermiás gépi perfúziót követően lehetőség nyílhat a szervek kontrollált, oxigenizált felmelegítésére (COR), ami normotermiás körülmények között teremt lehetőséget a viabilitási tesztek elvégzésére a beültetést megelőzően [30]. Sikeres állatkísérletes eredményeket követően a COR alkalmazása napjainkban jutott a klinikai transzláció fázisába, elsőként a májtranszplantációban $[31,32]$. 


\section{Normotermiás gépi veseperfúzió a klinikai gyakorlatban}

Biztató állatkísérletes eredmények [33-35] után a normotermiás $\left(37{ }^{\circ} \mathrm{C}\right.$ fok) veseperfúziót elsőként a brit Hosgood munkacsoport ültette a klinikai gyakorlatba 2011-ben [36]. Az első humán kontrollcsoportos vizsgálat során 18 ECD-donorból származó vesét 1 órán keresztül perfundáltak oxigenizált, véralapú perfúziós oldattal, normotermiás körülmények között. A klinikai utánkövetés eredményeit 47 , donor- és recipiensparaméterekre egyeztetett, statikus hidegtárolással konzervált $\mathrm{ECD}$-vese recipiensének eredményeivel hasonlították össze. A kezelt csoportban a DGF-ráta 36,2\%-ról 5,6\%-ra csökkent, azonban az egyéves grafttúlélés tekintetében nem mutatkozott szignifikáns különbség [37]. A Hosgood munkacsoport kifejlesztett és alkalmazott egy klinikai pontozási rendszert (EVNP-score), amely a gépi perfúzió során nyert paraméterek, így a makroszkópos megjelenés, az artériás áramlás és a vizeletkiválasztás alapján osztályozza a szerveket 1-től 5-ig terjedő skálán, ahol 1 pontot a legjobb minőségú, 5 pontot a legroszszabb minőségü szervek kapták [38]. A 64, előzetesen transzplantációra alkalmatlannak vélt vesegraftból 36 bizonyult alkalmasnak (1-3 EVNP-pont) és került beültetésre, melyek kivétel nélkül jól múködtek. A DGF-ráta $6 \%, 0 \%$, illetve $38 \%$ volt az 1,2 és 3 EVNP-pontot kapott csoportokban. Kimutatták továbbá, hogy egyes vizeletmarkerek, úgymint az ETl és az NGAL, szignifikánsan korreláltak a graftfunkcióval és az EVNP-pontokkal [39]. A normotermiás gépi perfúzió a prekondi-

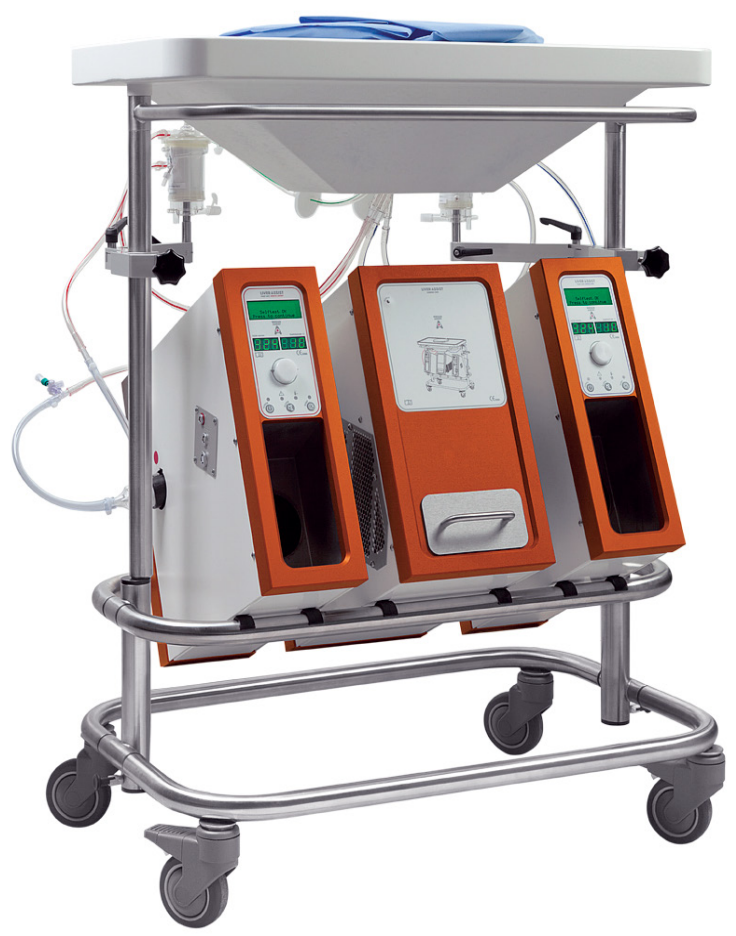

2. ábra

Normotermiás májperfúziós eszköz (Liver Assist ${ }^{\circledR}$, Organ Assist, Groningen, Hollandia; a cég engedélyével) cionálás mellett tehát lehetőséget teremt a szervek életképességének megítélésére, az átültetés előtti viabilitás vizsgálatára, így azoknak a szerveknek a kiválasztására, melyek beültetésre alkalmasak lennének, de hagyományos szervkonzerválás esetén nem kerülnének felhasználásra $[40,41]$.

\section{Gépi perfúzió a májtranszplantációban}

A májtranszplantáció gyakran az egyetlen életmentő lehetőség a végstádiumú májelégtelenségben szenvedő betegek számára. A májtranszplantáció még szélesebb körü alkalmazását leginkább a donorhiány korlátozza. Az egyre fokozódó szervhiány mellett a transzplantációs listán lévő betegek mortalitása világszerte évről évre nő. Míg a várólistán lévő betegek halálozása 2009-ben 11,1/100 várólistaév volt az UNOS adatbázisa alapján, 2014-re 12,3/100 várólistaévre növekedett [42]; számos régióban még a 30\%-ot is eléri [43]. A donorszelekciós kritériumok észszerü kiszélesítésével a transzplantációs programból lényegesen több beteg tudna profitálni. A kiterjesztett kritériumú (ECD) májak elfogadása és a DCD-donorkritériumok alkalmazása egy lehetséges stratégia a beültethető donorszervek számának növelésére. Ezen szerveknél azonban a csökkent ischaemiatolerancia miatt lényegesen gyakoribb a poszttranszplantációs morbiditás, úgymint a korai és késői epeúti szövődmények. Nagyállat-kísérletek és az első humán tanulmányok mára egyértelmúen bizonyították a gépi perfúzió előnyét a DCD- [44] és zsírmájak (a zsírtartalom nagyobb, mint $40 \%)$ átültetésekor.

\section{Hipotermiás gépi májperfúzió}

Guarrera és mtsai egy randomizált klinikai vizsgálatban igazolták elsőként az anoxiás hipotermiás gépi perfúzió előnyét kiterjesztett donorkritériumú graftoknál. $G u$ arrera az UNOS-régióban több centrum által lemondott májakat ültetett be HMP-rekondicionálást követően. A graftok minden esetben kiváló funkcióval indultak, alacsony enzimkiáramlás mellett, a mütét utáni kórházi tartózkodás és a társuló költségek pedig közel azonosak voltak, mint a statikusan hidegen tárolt, agyhalottból eltávolított graftok esetében [45]. Hasonlóan biztató eredményeket közöltek Dutkowski és mtsai, DCD- és zsírmájak 1 órás HOPE-rekondicionálása kapcsán. A kontroll-, statikusan hidegen tárolt graftokhoz képest a vizsgált szervekre alacsonyabb diszfunkciós ráta, kevesebb epeúti szövődmény és rövidebb kórházi ápolás volt jellemző, hasonló 1 éves grafttúlélés mellett [46-48].

\section{Normotermiás gépi májperfúzió}

Az NMP során a donorszervet tápanyagokkal dúsított, oxigenizált, véralapú perfuzátummal áramoltatják keresztül testhőmérsékleten, közel fiziológiás körülmények 
között közvetlenül a szervkivételt követően. A szövetek ATP-raktárai feltöltődnek, ezáltal csökken a reperfúziót követő oxidatív stressz, illetve az endothel-, mitokondrium- és szöveti károsodás [49]. Preklinikai kutatások és állatkísérletek után a 2010-es évek közepére a máj gépi perfúziós tárolása a klinikumban is biztonsággal alkalmazhatóvá vált.

A világon elsőként 2016-ban Ravikumar közölt klinikai eredményeket normotermiás gépi májperfúzióról. OrganOx Metra $^{\circledR}$ eszközt használva, 9,3 órás átlagos perfúziós idő során a májgraftok stabil hemodinamikai, szintetikus és exkréciós funkciókat mutattak stabil perfuzátumelektrolit és - pH fenntartása mellett. Bár a 30 napos graftmúködés tekintetében nem mutatkozott lényeges különbség a statikus hidegtárolással összehasonlítva, a közvetlen posztoperatív enzimkiáramlás szignifikánsan alacsonyabb volt [50]. A vizsgálatot számos, kisebb esetszámú tanulmány követte, az elsők között oxfordi, birminghami és torontói munkacsoportok végeztek sikeresen DCD- vagy kiterjesztett kritériumú donorokból származó graftokkal májtranszplantációt normotermiás gépi perfúziót követően [51-53].

Az első randomizált, kontrollált vizsgálatot Nasralla és mtsai végezték a COPE-vizsgálat keretei között, amelyben 220 májtranszplantáció során a statikus hidegtárolást hasonlították össze normotermiás gépi perfúzióval. Az eredményeket a Nature folyóiratban közölték [54]. A normotermiás gépi perfúzió a graftkárosodást jelző hepatocellularis enzimkiáramlást $50 \%$-kal csökkentette, 50\%-kal kevesebb májat utasítottak el, és 54\%-kal nőtt az átlagos szervkonzerválási idő. Az epeúti szövődmények, illetve a graft- és betegtúlélés szempontjából nem volt szignifikáns különbség a két csoport között. A vizsgálat fő klinikai haszna a várólista-mortalitás csökkentésének lehetősége azáltal, hogy több, korábban nem elfogadott máj kerülhet beültetésre. A normotermiás gépi májperfúzió ezenfelül lehetôvé teszi a hosszabb tárolást, így a mütét kedvezőbb ütemezését.

A normotermiás gépi perfúzió diagnosztikus modalitásként is használható, mivel lehetőség nyílik a tárolás alatt is funkcionáló, metabolikusan aktív graftok viabilitási paramétereinek elemzésére. Klinikai vizsgálatok és kutatási célra használt, beültetésre nem kerülő humán májgraftok perfúziós tapasztalatai alapján a laktátelimináció, a perfuzátumtranszamináz-szint, a glükózmetabolizmus, az epekiválasztás, az epe-pH, az oxigénfelhasználás és a hemodinamikai paraméterek egymással, illetve a várható graftfunkcióval összefüggést mutatnak $[55,56]$.

A normotermiás gépi perfúzió további előnye, hogy a tárolás időtartama alatt terápiás beavatkozásokra is lehetőség nyílik, így mesenchymalisőssejt-kezelésre, 'zsíroldásra' (defatting), immunológiai modifikációra, illetve génterápiára. Ezek az újszerú eljárások jelenleg prekilinikai kutatások tárgyát képezik $[57,58]$.

\section{Hasnyálmirigy gépi perfúzió}

A hasnyálmirigy gépi perfúziójának ötlete nem új keletű, már a transzplantáció hajnalán végeztek gépi perfúziós állatkísérleteket, melyek során elsősorban a perfundált hasnyálmirigy funkcióját elemezték [59]. Megállapították, hogy az inzulintermelés mérésével következtetni lehet a szervkárosodás mértékére [60]. A hasnyálmirigygraft optimális körülmények között történő tárolására a kezdeti gépi perfúziós korszakot követően több próbálkozás történt. A statikus hidegtárolás 1982-tôl váltotta le a körülményes és eredményeiben sem jobb kezdeti gépi hasnyálmirigy-perfúziót [61].

A hasnyálmirigy mint a „legérzékenyebb transzplantálható szerv" esetén az ideális konzerválási körülmények megteremtése és az ischaemiás károsodások minimalizálása talán még lényegesebb tényezője a transzplantáció kimenetelének, mint más szolid szervek esetében. A nem megfelelő konzerválás a vascularis szövődmények és a reperfúziót követő pancreatitis kialakulásában is szerepet játszik. A gépi perfúzióval történő hasnyálmirigykonzerválás eddig mégis kisebb figyelmet kapott a máj, a vese, a szív és a tüdő gépi perfúziójához képest. Ezt részben a hasnyálmirigy-transzplantációk számának elmúlt évtizedben tapasztalható visszaesése okozhatja, amit a komplikált 1-es típusú diabetes mellitus egyéb kezelési módszereinek fejlődése és a rövidebb várólisták miatt konzervatív donorkritériumok alkalmazása magyarázhat. A hasnyálmirigy- és a szimultán hasnyálmirigy-vesetranszplantáció életminőséget és élettartamot javító, de nem elhanyagolható morbiditással járó beavatkozás, ezért a kockázat és haszon kényes egyensúlyának fenntartása vált a legfontosabb mérlegelendő tényezővé [62]. A hasnyálmirigy-transzplantáció ugyanakkor eredményes kezelési módszer, a 3 éves inzulinmentes túlélés 90\% felett van, és a diabetes késői szövődményei is megelőzhetők általa. Ez alapján indokolt lenne több diabeteses beteg várólistára helyezése és egyúttal a donorszervek jobb hasznosítása [63].

A vese gépi perfúzió mintájára fejlesztették ki a hasnyálmirigy hipotermiás gépi perfúzióját, melynek célja más szervekhez hasonlóan az ischaemiás károsodás csökkentése, a felszaporodó toxikus anyagcseretermékek folyamatos eltávolítása, a vascularis rezisztencia mérésén keresztül a szervfunkció megítélése és aktív oxigenizálással az anaerob metabolizmus csökkentése.

$\mathrm{Az}$ anaerob metabolizmus csökkentése és az ATPszint növelése a tárolás folyamán a gépi perfúzió lehetőségétől függetlenül a kutatások középpontjába került, ez a célja az oxigénnel dúsított perfluorokarbon prezervációs oldat alkalmazásának, és a tárolás során történő oxigénperszufflációnak is [64-66].

A hasnyálmirigy gépi perfúzió nehézségét a komplex vérellátás, az alacsony áramlás és a más szervekhez viszonyítva nehezen beállítható ideális perfúziós paraméterek okozzák. A magas perfúziós nyomás endothelkárosodást és thrombosist okozhat, míg az alacsony nyomás nem 
megfelelő perfúzióhoz és oxigenizáláshoz vezethet. A hasnyálmirigy hipotermiás gépi perfúziója az interstitialis ödémát fokozza, ami Langerhans-szigetsejt-izolálás szempontjából akár előnyös is lehet, azonban teljes hasnyálmirigy-transzplantácó esetén a korszerű, megfelelő gépi perfúziós oldatok alkalmazásával elkerülendő [67, 68].

A hasnyálmirigy hipotermiás gépi perfúziójának humán alkalmazása a kezdeti fázisban tart, a közelmúltban két munkacsoport közölt biztató eredményeket összesen 15 hasnyálmirigy vizsgálatával. Az arteria mesenterica superior és az a. lienalis kanülálásával duális perfúzió alkalmazásával az elvárásoknak megfelelően emelkedő ATP-szintet, valamint csökkent sejtkárosodást jelző amiláz-, lipáz- és LDH-szinteket értek el, és IGLl-oldat alkalmazásával a gépi perfúzió nem okozott interstitialis ödémát $[69,70]$.

A hasnyálmirigy normotermiás gépi perfúzióját vizsgáló kísérletek igazolják, hogy a fiziológiás körülmények biztosítása a teljes konzerválási időtartam alatt kiemelt jelentőséggel bír. Barlow és mtsai transzplantációra alkalmatlannak ítélt humán hasnyálmirigy normotermiás gépi perfúzióját végezték 5 esetben, hidegtárolást követően. $\mathrm{Az}$ exokrin és endokrin funkció mérésével értékes eredményeket közöltek a konzerválás közben történő szervfunkció monitorozására. A biopsziával igazolt szöveti károsodás és ödéma mindegyik esetben jelentősnek bizonyult. A szerzők álláspontja szerint ez igazolja a gépi perfúziót megelőző hidegtárolás káros hatását, és alátámasztja a donorkórházba szállítható perfúziós eszközök fejlesztésének szükségességét más szervek esetén is [71, $72]$.

\section{Következtetések}

A kiterjesztett kritériumokkal elfogadható szervek gépi perfúziója a modern technikákkal fontos előrelépés a hasi szervek transzplantációjában, és egyúttal választ jelenthet a világszerte jellemző szervhiányra. A szuboptimális szervek felhasználása azonban kockázattal járhat a recipiens számára, ez pedig a csökkent ischaemiatoleranciából fakadó prezervációs károsodásnak tudható be. Állat- és humánvizsgálatok egyértelműen bizonyítják, hogy a gépi perfúzió csökkenti a reperfúziós szindróma, a korai graftdiszfunkció és graftvesztés, valamint a posztoperatív szövődmények előfordulását a fokozott kockázatú hasi szerveknél. Az úgynevezett rekondicionálás - az optimálisabb tárolási körülményeken túl - tovább javítható a perfúziós folyadék oxigenizálásával. A gépi perfúzió további előnye a statikus hidegtárolással szemben, hogy már a prezervációs periódus alatt a hemodinamikai, funkcionális vagy metabolikus paraméterek értékelése révén átfogóbb képet ad a szervek életképességéről és transzplantációra való alkalmasságáról. Ezáltal olyan szervek is beültethetővé válnak, melyeket a hagyományos szervkonzerválás mellett transzplantációra alkalmatlannak ítéltek volna.
A vesetranszplantációban a hipotermiás gépi perfúzió rutinszerú használata világszerte elterjedóben van. A gépi perfúzió térhódítását jelzi a holland és észak-amerikai gyakorlat: Hollandiában mára minden vese gépi perfúziós tárolásban részesül, míg az USA-ban minden második vese kerül pumpára. Evidenciaszintű bizonyítást nyert, hogy a HMP minden donortípusban csökkenti a késői graftindulás arányát, bár a hosszú távú előnyök tekintetében - az eddigi adatok alapján - csak az ECDdonoroknál bizonyult egyértelmúen hasznosnak. Az új generációs oxigenizált gépi perfúziós eszközök (LifePort $^{\circledR}$ 3.0, Kidney Assist ${ }^{\circledR}$ ) az elmúlt években kerültek piaci forgalomba, a tényleges gyakorlati előnyök feltérképezésére nagy betegszámú randomizált klinikai vizsgálatok szükségesek.

Állat- és humánkísérletes vizsgálatok alapján a máj gépi perfúziója nem jár lényeges előnyökkel a standard kritérium alapján szelektált donoroknál, akiknél már a hagyományos konzerválómódszerekkel is kiváló poszttranszplantációs eredmények érhetők el. A járulékos költségek, logisztikai kihívások, humánerőforrás-igény mellett a normotermiás prezerváció esetleges technikai hibájához társuló kockázatok miatt használatuk ebben a donorpopulációban egyébként sem célszerü. A magas kockázatú májgraftoknál, illetve a DCD- és zsírmájaknál lehet a gépi perfúziós tárolásnak a jövőben kiemelkedő szerepe. A preklinikai és klinikai adatok alapján a meleg és hideg gépi perfúzió egyaránt csökkenti a korai graftdiszfunkció, a reperfúziós szindróma és az epeúti szövődmények arányát, valamint növeli a transzplantálható szervek számát. A gépi perfúzió technológiájának optimalizálása jelenleg is kutatások tárgyát képezi, az új eljárások klinikai alkalmazhatóságának és költséghatékonyságának elemzéséhez további prospektív klinikai vizsgálatok szükségesek. A normotermiás perfúzió segítségével elérhetôvé válhat az is, hogy a transzplantációk „szemielektív” beavatkozássá válhassanak. A transzplantációk nappalra történő időzítésével valószínúsíthető az alacsonyabb szövődményráta, aminek további költségcsökkentő hatása lehet [54]. A gépi perfúzió alkalmazása új lehetôségeket teremt a transzplantációs hasi sebészetben, lehetőséget adva ezzel az átültetésre váró páciensek múködő grafttal történő túlélésének jelentős javítására, jobb életminőség mellett.

\section{Jövőkép}

A gépi perfúzió további, eddig még kevésbé kiaknázott lehetőségeket is tartogat. A metabolikusan és funkcionálisan aktív, izolált szervek már a szervtranszplantáció előtt, a prezerváció időtartama alatt gyógyszeresen prekondicionálhatók, vagy akár módosíthatók a recipiensre gyakorolt szisztémás mellékhatás nélkül. Számos ígéretes preklinikai kutatási eredményt közöltek új, korszerű eljárások egyidejű alkalmazásáról, így például az immunmodulácó, a génmódosítás, a nanoterápia lehetőségeiról is [73-75]. Kedvező eredményekről számoltak be egy, az 
endothelhez kötődő antikoaguláns ágens, a trombalexin használatáról, mely a mikrokapilláris keringés javítása révén a graftviabilitást, az anyagcsere-folyamatokat és az endothelfunkciót is javította [76]. Magyarországon $\mathrm{Fe}^{-}$ kete és mtsai patkány postischaemiás vesegraft funkcióját vizsgálták, melynek során egy új, Sigma-1-receptor által mediált, gyógyszeresen aktiválható renoprotektív útvonalat írtak le. A kutatócsoport szabadalma új lehetóségeket nyithat a vesegraft konzerválás közben történő kezelésében [74-75]. Máj esetén nagy figyelmet kaptak az úgynevezett „zsíroldó” eljárások, és az új terápiás célpontok között szerepelhet továbbá a mesenchymalisőssejt-terápia is a jövő gépi perfúziós kezelésének palettáján [71, 74, 75, 77]. A gépi perfúzió modern kori alkalmazásával olyan mérföldkőhöz érkeztünk, amely már napjainkban, illetve a közeljövőben számtalan új lehetôség felé nyithatja meg a transzplantációs sebészet kapuit, és alkalmat adhat a modern biotechnológia és a sebészet még szorosabb együttmúködésére.

Anyagi támogatás: A közlemény megírása anyagi támogatásban nem részesült.

Szerzői munkamegosztás: W. D.: Tervezés, az irodalom kutatása, a kézirat megszövegezése. H. M., Cs. O., T. Sz. J., R. B., R. Á.: Az irodalom kutatása, a kézirat megszövegezése. M. Z.: Tervezés, az irodalom kutatása, szerkesztés. A cikk végleges változatát mindegyik szerző elolvasta és jóváhagyta.

Érdekeltségek: A szerzóknek nincsenek érdekeltségeik.

\section{Irodalom}

[1] Clavien PA, Harvey PR, Strasberg SM. Preservation and reperfusion injuries in liver allografts. An overview and synthesis of current studies. Transplantation 1992; 53: 957-978.

[2] Chouchani ET, Pell VR, Gaude E, et al. Ischaemic accumulation of succinate controls reperfusion injury through mitochondrial ROS. Nature 2014; 515: 431-435

[3] Barnard CN. The operation. A human cardiac transplant: an interim report of a successful operation performed at Groote Schuur Hospital, Cape Town. S Afr Med J. 1967; 41: 1271-1274.

[4] A definition of irreversible coma: report of the Ad Hoc Committee of the Harvard Medical School to Examine the Definition of Brain Death. JAMA 1968; 205: 337-340.

[5] Florack G, Sutherland DE, Heil J, et al. Long-term preservation of segmental pancreas autografts. Surgery 1982; 92: 260-269.

[6] Cho YW, Terasaki PI, Cecka JM, et al. Transplantation of kidneys from donors whose hearts have stopped beating. N Engl J Med. 1998; 338: 221-225.

[7] Lindell SL, Compagnon P, Mangino MJ, et al. UW solution for hypothermic machine perfusion of warm ischemic kidneys. Transplantation 2005; 79: 1358-1361.

[8] Brasile L, Stubenitsky B, Booster M, et al. The cadaveric kidney and the organ shortage - a perspective review. Clin Transplant. 2001; 15: 369-374.

[9] Frei U, Noeldeke J, Machold-Fabrizii V, et al. Prospective agematching in elderly kidney transplant recipients - a 5-year analysis of the Eurotransplant Senior Program. Am J Transplant. 2008; 8: 50-57.
[10] Perico N, Cattaneo D, Sayegh MH, et al. Delayed graft function in kidney transplantation. Lancet 2004; 364: 1814-1827.

[11] Treckmann J, Moers C, Smits JM, et al. Machine perfusion versus cold storage for preservation of kidneys from expanded criteria donors after brain death. Transplant Int. 201 1; 24: 548-554

[12] Szwarc I, Garrigue V, Delmas S, et al. Delayed graft function: a frequent but still unsolved problem in renal transplantation. Nephrol Ther. 2005; 1: 325-334.

[13] Hamar M, Selzner M. Ex-vivo machine perfusion for kidney preservation. Curr Opin Organ Transplant. 2018; 23: 369-374.

[14] Moers C, Smits JM, Maathuis MH, et al. Machine perfusion or cold storage in deceased-donor kidney transplantation. $\mathrm{N} \mathrm{Engl} \mathrm{J}$ Med. 2009; 360: 7-19.

[15] Lam VW, Laurence JM, Richardson AJ, et al. Hypothermic ma chine perfusion in deceased donor kidney transplantation: a systematic review. J Surg Res. 2013; 180: 176-182.

[16] O'Callaghan JM, Morgan RD, Knight SR, et al. Systematic review and meta-analysis of hypothermic machine perfusion versus static cold storage of kidney allografts on transplant outcomes. Br J Surg. 2013; 100: 991-1001.

[17] Hameed AM, Pleass HC, Wong G, et al. Maximizing kidneys for transplantation using machine perfusion: from the past to the future: a comprehensive systematic review and meta-analysis. Medicine (Baltimore) 2016; 95: e5083.

[18] Deng R, Gu G, Wang D, et al. Machine perfusion versus cold storage of kidneys derived from donation after cardiac death: a meta-analysis. PLoS ONE 2013; 8: e56368.

[19] Jochmans I, Moers C, Smits JM, et al. Machine perfusion versus cold storage for the preservation of kidneys donated after cardiac death: a multicenter, randomized, controlled trial. Ann Surg. 2010; 252: 756-764.

[20] Watson CJ, Wells AC, Roberts RJ, et al. Cold machine perfusion versus static cold storage of kidneys donated after cardiac death: a UK multicenter randomized controlled trial. Am J Transplant. 2010; 10: 1991-1999.

[21] Moers C, Pirenne J, Paul A, et al. Machine perfusion or cold storage in deceased-donor kidney transplantation. $\mathrm{N}$ Engl $\mathrm{J}$ Med. 2012; 366: 770- 771.

[22] Gallinat A, Moers C, Smits JM, et al. Machine perfusion versus static cold storage in expanded criteria donor kidney transplantation: 3-year follow-up data. Transpl Int. 2013; 26: E52-E53.

[23] Jochmans I, Moers C, Smits JM, et al. The prognostic value of renal resistance during hypothermic machine perfusion of deceased donor kidneys. Am J Transplant. 2011; 11: 2214-2220.

[24] de Vries EE, Hoogland ER, Winkens B, et al. Renovascular resistance of machine-perfused DCD kidneys is associated with primary nonfunction. Am J Transplant. 2011; 11: 2685-2691.

[25] Bhangoo RS, Hall IE, Reese PP, et al. Deceased-donor kidney perfusate and urine biomarkers for kidney allograft outcomes: a systematic review. Nephrol Dial Transplant. 2012; 27: 33053314.

[26] Moers C, Varnav OC, van Heurn E, et al. The value of machine perfusion perfusate biomarkers for predicting kidney transplant outcome. Transplantation 2010; 90: 966-973.

[27] Hoogland ER, de Vries EE, Christiaans MH, et al. The value of machine perfusion biomarker concentration in DCD kidney transplantations. Transplantation 2013; 95: 603-610.

[28] Parikh CR, Hall IE, Bhangoo RS, et al. Associations of perfusate biomarkers and pump parameters with delayed graft function and deceased donor kidney allograft function. Am J Transplant. 2016; 16: 1526-1539.

[29] 't Hart NA, van der Plaats A, Faber A, et al. Oxygenation during hypothermic rat liver preservation: an in vitro slice study to demonstrate beneficial or toxic oxygenation effects. Liver Transpl. 2005; 11: 1403-1411.

[30] Minor T, Sutschet K, Witzke O, et al. Prediction of renal function upon reperfusion by ex situ controlled oxygenated rewarming. Eur J Clin Invest. 2016; 46: 1024-1030. 
[31] Hoyer DP, Máthé Z, Gallinat A, et al. Controlled oxygenated rewarming of cold stored livers prior to transplantation: first clinical application of a new concept. Transplantation 2016; 100: 147-152.

[32] von Horn C, Baba HA, Hannaert P, et al. Controlled oxygenated rewarming up to normothermia for pretransplant reconditioning of liver grafts. Clin Transplant. 2017; 31: e13101.

[33] Bagul A, Hosgood SA, Kaushik M, et al. Experimental renal preservation by normothermic resuscitation perfusion with autologous blood. Br J Surg. 2008; 95: 111-118.

[34] Hosgood SA, Barlow AD, Yates PJ, et al. A pilot study assessing the feasibility of a short period of normothermic preservation in an experimental model of non heart beating donor kidneys. J Surg Res. 2011; 171: 283-290.

[35] Hosgood SA, Patel M, Nicholson ML. The conditioning effect of ex vivo normothermic perfusion in an experimental kidney model. J Surg Res. 2013; 182: 153-160.

[36] Hosgood SA, Nicholson ML. First in man renal transplantation after $e x$ vivo normothermic perfusion. Transplantation 2011; 92: 735-738.

[37] Nicholson ML, Hosgood SA. Renal transplantation after ex vivo normothermic perfusion: the first clinical study. Am J Transplant. 2013; 13: 1246-1252.

[38] Hosgood SA, Barlow AD, Hunter JP, et al. Ex vivo normothermic perfusion for quality assessment of marginal donor kidney transplants. Br J Surg. 2015; 102: 1433-1440.

[39] Hosgood SA, Nicholson ML. An assessment of urinary biomarkers in a series of declined human kidneys measured during ex vivo normothermic kidney perfusion. Transplantation 2017; 101: 2120-2125

[40] Hosgood SA, Saeb-Parsy K, Hamed MO, et al. Successful transplantation of human kidneys deemed untranspantable but resus citated by ex vivo normothermic machine perfusion. Am J Transplant. 2016; 16: 3282-3285.

[41] Hosgood SA, Thompson E, Moore T, et al. Normothermic machine perfusion for the assessment and transplantation of declined human kidneys from donation after circulatory death donors. Br J Surg. 2018; 105: 388-394.

[42] Increasing the number of transplants in the United States. 2016 in review. Available from: https://unos.org/about/annualreport/2016-annual-report/ [accessed: June 25, 2018].

[43] Kim WR, Lake JR, Smith JM et al. OPTN/SRTR 2016 Annual Data Report: Liver. Am J Transplant. 2018; 18(Suppl 1): 172 253.

[44] Nemes B, Gámán G, Polak WG et al. Extended-criteria donors in liver transplantation Part II: reviewing the impact of extendedcriteria donors on the complications and outcomes of liver transplantation. Expert Rev Gastroenterol Hepatol. 2016; 10: 841859.

[45] Guarrera JV, Henry SD, Samstein B, et al. Hypothermic machine preservation facilitates successful transplantation of 'orphan' extended criteria donor livers. Am J Transplant. 2015; 15: 161169.

[46] Dutkowski P, Schlegel A, de Oliveira M, et al. HOPE for human liver grafts obtained from donors after cardiac death. J Hepatol. 2014; 60: 765-772.

[47] Dutkowski P, Polak WG, Muiesan P, et al. First comparison of hypothermic oxygenated perfusion versus static cold storage of human donation after cardiac death liver transplants: an international-matched case analysis. Ann Surg. 2015; 262: 764-770.

[48] de Rougemont O, Breitenstein S, Leskosek B, et al. One hour hypothermic oxygenated perfusion (HOPE) protects nonviable liver allografts donated after cardiac death. Ann Surg. 2009; 250: 674-683.

[49] Brockmann J, Reddy S, Coussios C, et al. Normothermic perfusion: a new paradigm for organ preservation. Ann Surg. 2009; 250: 1-6.
[50] Ravikumar R, Jassem W, Mergental H, et al. Liver transplanta tion after ex vivo normothermic machine preservation: a phase $\mathrm{I}$ (first-in-man) clinical trial. Am J Transplant. 2016; 16: 17791787.

[51] Perera T, Mergental H, Stephenson B, et al. First human liver transplantation using a marginal allograft resuscitated by normothermic machine perfusion. Liver Transpl. 2016; 22: 120-124.

[52] Mergental H, Perera MT, Laing RW et al. Transplantation of declined liver allografts following normothermic ex-situ evaluation. Am J Transplant. 2016; 16: 3235-3245.

[53] Selzner M, Goldaracena N, Echeverri J, et al. Normothermic ex vivo liver perfusion using steen solution as perfusate for human liver transplantation: first North American results. Liver Transpl. 2016; 22: 1501-1508.

[54] Nasralla D, Coussios CC, Mergental H, et al. Consortium for Organ Preservation in Europe. A randomized trial of normothermic preservation in liver transplantation. Nature 2018; 557: 50-56.

[55] Allard MA, Castro-Benitez C, Imai K, et al. Suitability of livers for transplantation when treated by normothermic machine perfusion. Clin Transplant. 2018; 32: el3256.

[56] Sutton ME, op den Dries S, Karimian N, et al. Criteria for viability assessment of discarded human donor livers during ex vivo normothermic machine perfusion. PLoS ONE 2014; 9: el10642.

[57] Jamieson RW, Zilvetti M, Roy D, et al. Hepatic steatosis and normothermic perfusion-preliminary experiments in a porcine model. Transplantation 2011; 92: 289-295.

[58] Nagrath D, Xu H, Tanimura Y, et al. Metabolic preconditioning of donor organs: defatting fatty livers by normothermic perfusion ex vivo. Metab Eng. 2009; 11: 274-283.

[59] Florack G, Sutherland DE, Heil J, et al. Preservation of canine segmental pancreatic autografts: cold storage versus pulsatile machine perfusion. J Surg Res. 1983; 34: 493-504.

[60] Babkin BP, Starling EH. A method for the study of the perfused pancreas. J Physiol. 1926; 61: 245-247.

[61] Ali F, Dua A, Cronin DC. Changing paradigms in organ preservation and resuscitation. Curr Opin Organ Transplant. 2015; 20: 152-158.

[62] Stratta RJ, Fridell JA, Gruessner AC, et al. Pancreas transplantation: a decade of decline. Curr Opin Organ Transplant. 2016; 21: 386-392.

[63] Stratta RJ, Gruessner AC, Odorico JS, et al. Pancreas transplantation: an alarming crisis in confidence. Am J Transplant. 2016; 16: 2556-2562.

[64] Agrawal A, So P, Penman A. Limited penetration of perfluorocarbon in porcine pancreas preserved by two-layer method with (19)fluorine magnetic resonance spectroscopy and headspace gas chromatography. Cell Transplant. 2010; 19: 1021-1029.

[65] Kawamura T, Kuroda Y, Suzuki Y, et al. Seventy-two-hour preservation of the canine pancreas by the two-layer (EuroCollins' solution/perfluorochemical) cold storage method. Transplantation 1989; 47: 776-778.

[66] Matsumoto S, Kandaswamy R, Sutherland D. Clinical application of the two-layer (University of Wisconsin solution/peflurochemical plus $\mathrm{O}_{2}$ ) method of pancreas preservation before transplantation. Transplantation 2000; 70: 771-774.

[67] Taylor MJ, Baicu S, Leman B. Twenty-four hour hypothermic machine perfusion preservation of porcine pancreas facilitates processing for islet isolation. Transplant Proc. 2008; 40: 480482.

[68] Karcz M, Cook HT, Sibbons P, et al. An ex-vivo model for hypothermic pulsatile perfusion of porcine pancreata: haemodynamic and morphologic charateristics. Exp Clin Transplant. 2010; 8: $55-60$.

[69] Cantarovich D, Renaudin K, Branchereau J. Preservation of human pancreas with hypothermic machine perfusion. TTS Aug 2016. 
[70] Leemkuil M, Engelse M, Ploeg R, et al. Hypothermic machine perfusion improves the quality of marginal donor pancreata. Am J Transplant. 2015; 15 (Suppl 3). https://atcmeetingabstracts. com/abstract/hypothermic-machine-perfusion-improves-thequality-of-marginal-donor-pancreata/ [accessed: September 26, 2018].

[71] Barlow AD, Hamed MO, Mallon DH, et al. Use of ex vivo normothermic perfusion for quality assessment of discarded human donor pancreases. Am J Transplant. 2015; 15: 2475-2482.

[72] Dholakia S, Royston E, Sharples EJ, et al. Preserving and perfusing the allograft pancreas: past, present, and future. Transplant Rev (Orlando). 2018; 32: 127-131.

[73] Pareta R, Sanders B, Babbar P, et al. Immunoisolation: where regenerative medicine meets solid organ transplantation. Expert Rev Clin Immunol. 2012; 8: 685-692.

[74] Hamaoui K, Aftab A, Gowers S, et al. An ex vivo comparison of adenosine and lidocaine solution and University of Wisconsin solution for hypothermic machine perfusion of porcine kidneys: potential for development. J Surg Res. 2017; 208: 219-229.
[75] Hitchman E, Hitchman RB, King LA. BacMam delivery of a protective gene to reduce renal ischemia-reperfusion injury. Hum Gene Ther. 2017; 28: 747-756.

[76] Hamaoui K, Gowers S, Boutelle M, et al. Organ pretreatment with cytotopic endothelial localizing peptides to ameliorate microvascular thrombosis and perfusion deficits in ex vivo renal hemoreperfusion models. Transplantation 2016; 100: el28el39.

[77] Gregorini M, Corradetti V, Pattonieri EF, et al. Perfusion of isolated rat kidney with mesenchymal stromal cells/extracellular vesicles prevent ischaemic injury. J Cell Mol Med. 2017; 21: 3381-3393.

(Máthé Zoltán dr., Budapest, Baross u. 23., 1082 e-mail: mathe.zoltan@med.semmelweis-univ.hu) feltéve, hogy az eredeti szerző és a közlés helye, illetve a CC License linkje és az esetlegesen végrehajtott módosítások feltüntetésre kerülnek. 